\title{
MATE-POACHING AND MATING SUCCESS IN HUMANS
}

\author{
STEVEN ARNOCKY, ${ }^{1, *}$ SHAFIK SUNDERANI ${ }^{2}$ AND TRACY VAILLANCOURT ${ }^{3}$ \\ ${ }^{1}$ Nipissing University, Ontario, Canada \\ ${ }^{2}$ University of Toronto, Ontario, Canada \\ ${ }^{3}$ University of Ottawa, Ontario, Canada
}

\begin{abstract}
It has been suggested that mate-poaching behavior is an evolutionarily-adaptive mating tactic. The purpose of this study was to examine the relationship between lifetime number of mate-poaching attempts and mating success in a sample of 271 (147 women and124 men) heterosexual undergraduate students. Results indicated that for both men and women, the number of mate-poaching attempts predicted having more lifetime sex partners, more lifetime casual sex partners, and more lifetime dating partners. Mate-poaching attempts did not however, predict differences in the attractiveness and social dominance of one's most recent partner. These results provide evidence of the efficacy of mate-poaching in predicting mating success.
\end{abstract}

Keywords: mate-poaching, mating success, sexual behavior, infidelity

\section{MATE-POACHING AND MATING SUCCESS IN HUMANS}

In the arena of human mating, some individuals will vie for the affection of a person who is already in a romantic relationship - a behavioral tactic termed "matepoaching" (SCHMITT et al. 2004; SCHMITT and BUSS 2001). Successful matepoaching results in a new mating opportunity for both the poacher and the poached (i.e., the target of the poacher); and this new mateship can range from a short-term extra-pair sexual encounter to the formation of a new long-term romantic pair bond (SCHMITT and Buss 2001).

Mate-poaching has been observed among various species (DAWKINS and KREBS 1978; DEWAAL 1986; TRIVERS 1985) and across diverse human cultural groups (e.g., SCHMITT et al. 2004). On the surface, mate-poaching among humans may seem perplexing given that efforts directed at stealing someone else's partner can be both arduous and risky (see DAVIES, SHACKELFORD and HASS 2010; SCHMITT and BUSS 2001). First, mate-poaching attempts, compared to attempts at attracting an unmated individual, relate to greater odds of rejection from the target. For instance, SCHMITT and BUSS (2001) found that poaching tactics were perceived as being less effective when attempting to infiltrate a highly committed relationship (e.g., marriage) compared to attempts at enticing less-committed individuals (SCHMITT and Buss 2001). Second, undesirable feelings of stress, guilt, and selfdegradation can result from engaging in mate-poaching behavior or from commit-

${ }^{*}$ Address for correspondence: ${ }^{1}$ STEVEn ARNOCKY, Ph.D. Nipissing University, Ontario, Canada e-mail: stevena@nipissingu.ca 
ting an infidelity (DAVIES et al. 2010; SCHMITT and BuSS 2001). Third, matepoaching can elicit acts of retaliation from the cuckold as well as sanction from the social group (DALY and WILSON 1989; DAVIES et al. 2010; SCHMITT and SHACKELFORD 2003). Accordingly, mate-poaching strategies are often surreptitious and indirect. For example, mate-poaching strategies include glancing at the desired mate, subtly displaying resources to the target, or infiltrating the relationship or social network in order to plant "seeds of dissatisfaction" within the existing pairbond (e.g., SCHMITT et al. 2004; SCHMITT and BUSS 2001). Mate-poachers who are themselves currently involved in a romantic relationship will engage in actions such lying to or manipulating their current partner, keeping him/herself out of town, establishing their independence, and increasing relationship affection or resource commitment to the current partner - all in an effort to mask their poaching behavior and quell any suspicions of infidelity (SCHMITT and SHACKELFORD 2003).

Given the potentially negative consequences, as well as the significant effort necessary to mate-poach, it is logical to pose the question: Why would men and women engage in mate-poaching behavior when the local mating pool usually consists of unpaired individuals with whom mating would be less challenging? Researchers speculate that over human evolutionary history, those individuals who had psychological mechanisms in place which motivated them to mate (or attempt to mate) with already-paired individuals were at a reproductive advantage compared to those individuals who were motivated to mate solely with unpaired individuals (see BUSS 2006; PARKER and BURKLEY 2009; SCHMITT and BUSS 2001; SCHMITT 2004; SUNDERANI, ARNOCKY and VAILLANCOURT 2013). Specifically, mate-poaching might have conferred a wider array of mating opportunities, perhaps including relations with some of the most desirable and reproductively viable members of the opposite sex, who themselves were more likely to be already engaged in a pair-bond (SCHMITT and Buss 2001).

The concept of mate-poaching as an adaptive sexual tactic is predicated on the assumption that it has, over deep evolutionary time, been effective in enhancing individuals' mating success (BUSS 2006; 2007; SCHMITT et al. 2001; SCHMITT et al. 2004), yet hitherto there is a paucity of research examining this relationship. In the present study, we examined three potential benefits of human mate-poaching as they relate to various indicators of mating success: short-term sexual access, partner acquisition/relationship formation, and mate-quality.

\section{Poaching for short-term mating opportunity}

In one study examining mate-poaching behavior across different countries, approximately $57 \%$ of men and $35 \%$ of women reported having attempted a matepoach for the purpose of short-term mating (SCHMITT et al. 2004). DAVIES, SHACKELFORD and GOETZ (2006a) suggested that one benefit of men's matepoaching behavior may be the ability to procure opportunities for short-term casual sex with women who already have invested romantic partners. Given that men, 
compared to women, invest relatively little obligatory reproductive energies into any child (TRIVERS 1972), a man can benefit his reproductive fitness by having numerous mates. DAVIES, SHACKELFORD and GOETZ (2006b) further noted that "accordingly, men are expected to have an evolved psychology that motivates them to welcome opportunities which might enable them to avoid depleting their own resources through having other men unknowingly invest in their offspring - especially likely when poaching, as a poached woman already has a long-term partner" (p. 303). Women, having substantial requisite parental investment, are more selective in their mate choice (TRIVERS 1972) and as such, investment cannot be avoided through poaching behavior. However, it is important to note that in previous studies, a significant proportion of women report having also attempted poaching for the purposes of short-term mating (e.g., SCHMITT et al. 2004). Researchers have suggested that women engage in casual sex in order to procure "good genes" (WEATHERHEAD and ROBERTSON 1979; YASUI 1997). Having sex with multiple men in a short-period of time can lead to sperm competition creating a situation whereby the sperm with the greatest motility, and that can best withstand the acidity of the cervical mucus, is more likely to fertilize the women's egg, offering the best genes available in the pool (e.g., BAKER and BELLIS 1995; GOETZ et al. 2005; SHACKELFORD, POUND and GOETZ, 2005; SMITH 1984). SCHMITT and BuSS (2001) suggested that women seem to preferentially poach men who exhibit "good gene" characteristics such as physical attractiveness (SUNDERANI et al. 2013); and these women will sometimes return to their long-term partners, potentially resulting in cuckoldry (see also GANGESTAD and THORNHILL 1997).

An alternative explanation for women's short-term mating is known as the mate-switching hypothesis. GREILING and BUSS (2000) found that women were more likely report extra-pair copulations if they perceived the extraneous partner to be more desirable than their current partner. Interestingly, women engaging in extra-pair sexual relations reported it easier to break-up with their current partner. GREILING and BUSS (2000) further showed that women are more likely to engage in an extra-pair sexual liaison if their current partner is abusive, is unwilling to have sex, and/or is cheating on her. Taken together, we expected that the number of times in which men and women have attempted a mate-poach will predict having had more lifetime sex partners, and in particular more lifetime casual sex partners as an indication of short-term reproductive opportunities.

\section{Poaching for longer-term mating opportunity}

Despite the pervasiveness of short-term sexual relations among humans, in modern Western society, most individuals tend to establish, compete for, and maintain longterm romantic relationships rather than pursuing solely short-term sexual encounters (e.g., ARnocky et al. 2012; Miller, Putcha-Bhagavatula and Pedersen 2002). Monogamy and long-term pair bonding are suggested to result from women's preferences for men who invest heavily in offspring (BUUNK and FISHER 
2009), combined with attempts on the part of men to insure paternity through mateguarding behaviors (for review, see BENSHOOF and THORNHILL 1979; MARLOWE 2000). SCHMITT and BUSS (2001) suggest that mate-poaching can benefit long-term mating strategies via relationship takeover, whereby the initial pair-bond dissolves and the desired individual establishes a new relationship with the mate-poacher. The authors further suggested that this is evidenced by culturally universal patterns of serial monogamy, where mate-poaches often result in the consecutive formation of new mating relationships (SCHMITT and BUSS 2001). Fifty-seven percent of men and $44 \%$ of women report having attempted a mate-poach for the purposes of longterm mating (i.e., a mateship lasting beyond a casual one-night stand; SCHMITT et al. 2004); therefore we also expected an individual's number of mate-poaching attempts would predict a greater number of lifetime dating partners.

\section{Poaching for partner quality}

Finally, mate-poaching might also influence the quality of partner available to the individual. Obtaining a partner of high mate-value can benefit reproductive success. For instance, across various cultural contexts, women who attract high status men have been found to produce more surviving offspring compared to women who mated with lower status partners (e.g., BERECZKEI and CSANSKY 1996; VOLAND and ENGEL 1990). Similarly, physical attractiveness (as a marker for the genetic quality of a partner) among men and women has been associated with sperm quality and fertility, respectively (c.f. GALLUP and FREDERICK 2010), as well as increased sexual behavior (WEEDEN and SABINI 2007) and reproductive success in both industrialized and hunter-gatherer societies (HILL and HURTANDO 1996; JOKELA 2009). However, individuals who are of higher mate-value are also more likely to be desired by others (BUSS 1989; HA, OVERBEEK and ENGELS 2010). As one example, attractive females are more likely to be asked out on dates (WALSTER et al. 1966). If the most desirable members of the opposite sex also tend to be involved in an existing romantic relationship, then an individual can improve his/her own mating success by attempting to steal these more desirable mates away from his/her intrasexual competitors.

Indeed, women's use of mate poaching may reflect their preference for men who are already selected for by other women; a phenomenon termed mate-choice copying (e.g., GRAZIANO et al. 1993; PARKER and BURKLEY 2009). WAYNFORTH (2007) suggests that women evaluate men who are in existing relationships as being more desirable when there is a lack of information available to them to form their judgement. Recent evidence has supported the existence of the mate-copying effect in men, whereby both men and women showed more short-term and long-term mating interest in members of the opposite sex when shown videos of that person engaging in a successful speed-date with another partner (PLACE at el. 2010). Matechoice copying may help to explain mate-poaching behavior, although this effect has not been consistently demonstrated in the research (see ULLER and JOHANAS- 
SON 2003). Therefore, we also expect number of mate-poaching attempts to predict having more desirable partners.

\section{The present study}

To the best of our knowledge, no study has yet examined whether the number of mate-poaching attempts is associated with increased mating success. Researchers have suggested that individuals who employ a mate-poaching tactic may likely have more sexual and dating partners (perhaps of higher quality or mate-value) compared to those who less frequent attempt mate-poaching. However, this presumption remains empirically untested. In the present study, we explore whether the number of mate-poaching attempts is associated with greater mating success. We hypothesized that men and women who report a greater number of mate-poaching attempts would have a greater number of lifetime sexual partners (H1a) and more casual sex partners (H1b) compared to men and women who are less frequent poachers. Our second hypothesis is focused on accessing romantic (i.e., dating) partners. We predicted that individuals' number of mate-poaching attempts to predict more lifetime dating partners (H2). Finally, we hypothesized that number of mate-poaching attempts would predict having a most recent dating partner of higher mate-value (H3). Inherent in these predictions is the proposition that employing a risky mating tactic of mate-poaching confers enhanced mating opportunity. Using path analysis, we tested a model based on these predictions separately for men and women, while simultaneously controlling for participant age, which has also been shown to be associated with dating and sexual behavior (e.g., BAUMEISTER, CATANESE and VOHS 2001).

\section{METHOD}

\section{Participants}

Two hundred and seventy one heterosexual students $\left(\mathrm{n}_{\text {women }}=147, \mathrm{M}_{\text {age }}=19, \mathrm{SD}=\right.$ $0.69 ; \mathrm{n}_{\mathrm{men}}=124, \mathrm{M}_{\mathrm{age}}=19, \mathrm{SD}=1.0$ ) completed questionnaires pertaining to their interpersonal and sexual behavior. Recruitment took place at two mid-sized Ontario universities (one in Southern Ontario and one in Northern Ontario) via posters describing the study which were located in common areas (residence buildings, cafeterias), and through classroom recruitment. The ethnic distribution of the sample was of primarily of White-European descent $(58 \%)$, followed by South Asian $(18 \%)$, mixed ethnicity (10\%), Asian (9\%), Latin-American (2\%), Black (2\%), and Arab (1\%) descent. The size of our sample allowed us to explore hypotheses separately for men and women, whilst maintaining an acceptable number of cases per parameter in our path model (see KLINE 2005). Participant sexuality was determined using the following item: "Which of the following best describes your sexual 
orientation?" with response options being "heterosexual, lesbian/gay, bisexual, or other".

\section{Mate-poaching}

Participants were first provided with a brief narrative explaining the concept of mate poaching as knowingly behaving in a manner meant to lure an already mated individual away from their current partner for some romantic or sexual purpose (see also DAVIES, SHACKELFORD and HASS 2007). The description provided in the current study, based on SUNDERANI et al. (2013), was presented as follows:

Sometimes people try to romantically attract one another. On occasion, people try to attract someone who is already in a romantic relationship. For example, a woman may try to attract a man even though he is already dating, in a relationship with or married to another woman. She might do this for a short-term sexual affair with him or to try and obtain him for long-term relationship. Mate-poaching then is attracting (or trying to attract) someone away from their current partner (originally adapted from SCHMITT and BUSS 2001).

Participants then reported on a 9-point Likert-scale $(0=$ never to $8=$ eight or more times) their total number of lifetime mate-poaching attempts using the following two items: "How often have you successfully poached someone away from a past partner?" and "How often have you attempted to try to poach someone away from their relationship with someone else unsuccessfully?" (see SUNDERANI et al. 2013). These items were summed to provide a total count of lifetime mate-poaching attempts.

\section{Mating success variables}

Previous research in the field of evolutionary psychology has conceptualized mating success as comprising both copulatory behaviors, such as the frequency of intercourse or the number of sexual partners (e.g., HODGES-SiMEON, GAULIN and PUTS 2011), as well as the ability to attain dating or romantic partners (e.g., RHODES et al. 2005). In assessing participants' sexual behaviors, respondents selfreported on their number of consensual lifetime sex partners, and their number of consensual casual sex partners where casual sex was defined as "a sexual partner who you were NOT in an exclusive, committed relationship with". In assessing participants' dating behaviors, respondents self-reported the number of exclusive dating partners they have had in their lifetime (ABBEY and Ross 1996).

In assessing romantic partner quality, participants were then asked to evaluate their most recent or current romantic partner on a limited number of agerepresentative mate-value items derived from previous research as being appealing to adolescents/emerging adults. In a sample of adolescents, HA, OVERBEEK, RUT- 
GER and ENGELS (2010) found that boys prioritized physically attractive girls, and that girls prioritize physically attractive, high-status boys. Given the mean age of our undergraduate sample, the following partner-quality items were assessed as mate-value characteristics of the participant's most recent romantic partner (using a 7-point Likert scale ranging from $1=$ Not at all to $7=$ Very much): "How cool he/she is?", "How sexy he/she is?", "How appealing your partner is to others your same age and gender?", "How able he/she is to sexually satisfy you?" In the present study, the partner quality measure was internally consistent, $\alpha=0.83$ (men $\alpha=$ 0.84 ; women $\alpha=0.81$ ).

\section{Analytic approach}

A theoretical path model was designed which predicted the number of matepoaching attempts to be associated with mating success variables (number of lifetime sex partners, number of lifetime casual sex partners, lifetime number of dating partners, and self-perceived quality of the most recent romantic partner), while statistically controlling for age.

Path analysis has a number of distinct advantages over ordinary least-squares regression such as allowing us to test simultaneous predictions of the relationship between mate-poaching and various mating benefit variables of different types (count and continuous). For this reason, it has been successfully employed in previous research using counts of various sexual activities as criterion variables (e.g., Kalichman, Heckman and Kelly 1996; Schroder, Carey and Vanable 2003).

For each model, overall fit was assessed using the following indices: the chisquare test of significance $\left(\chi^{2}\right)$; comparative fit index (CFI); and root mean square error of approximation (RMSEA; KLINE 2005). Good model fit is indicated by an insignificant model chi-square. An RMSEA below .07 and a CFI above .90 are also indicative of good model fit. We compared differences in fit between our models using the Akaike information criterion (AIC) scores whereby lower values suggest better fit (KENNY 2000).

\section{RESULTS}

\section{Descriptive Statistics}

Descriptive statistics and bivariate correlations for each measure are provided in Table 1. At the bivariate level, men's number of mate-poaching attempts were significantly and positively correlated with lifetime number of sex partners $(r=.51$, $p<.01)$ and lifetime number of casual sex partners $(r=.26, p<.01)$. Frequency of mate-poaching attempts was not correlated with lifetime number of dating partners nor with self-perceived quality of their current romantic partner. Women's matepoaching attempts were significantly and positively correlated with lifetime number of sex partners $(r=.27, p<.01)$, lifetime number of casual sex partners $(r=.28$, 
$p<.01)$, and lifetime number of dating partners $(r=.32, p<.01)$. See Table 2 for all bivariate correlations.

Table 1. Descriptive statistics by sex

\begin{tabular}{lcccccccc}
\hline & $N$ & \multicolumn{3}{c}{$M$} & \multicolumn{3}{c}{$S D$} & \multicolumn{3}{c}{ Range } \\
\cline { 2 - 9 } & Male & Female & Male & Female & Male & Female & Male & Female \\
\hline 1. Age & 124 & 147 & 19 & 19 & 1.00 & 0.69 & $17-23$ & $17-36$ \\
\hline $\begin{array}{l}\text { 2. Mate-poaching } \\
\text { attempts }\end{array}$ & 121 & 147 & 1.49 & 1.22 & 2.86 & 2.15 & $0-16$ & $0-16$ \\
\hline $\begin{array}{l}\text { 3. Lifetime sex } \\
\text { partners }\end{array}$ & 122 & 146 & 4.25 & 3.30 & 7.28 & 5.18 & $0-60$ & $0-25$ \\
\hline $\begin{array}{l}\text { 4. Lifetime casual } \\
\text { sex partners }\end{array}$ & 120 & 143 & 2.22 & 1.63 & 4.24 & 3.48 & $0-24$ & $0-20$ \\
\hline $\begin{array}{l}\text { 5. Lifetime dating } \\
\text { partners }\end{array}$ & 121 & 142 & 3.47 & 2.92 & 3.13 & 2.81 & $0-10$ & $0-22$ \\
\hline 6. Partner quality & 109 & 125 & 5.73 & 5.16 & 1.05 & 1.17 & $2.8-7$ & $2-7$ \\
\hline
\end{tabular}

Table 2. Bivariate correlations. Male data are presented below the diagonal, female data are presented above the diagonal

\begin{tabular}{lcccccc}
\hline & 1 & 2 & 3 & 4 & 5 & 6 \\
\hline 1. Age & - & .28 & $.60^{* *}$ & -.14 & $.45^{* *}$ & -.08 \\
\hline 2. Mate-poaching attempts & .11 & & $.27^{* *}$ & $28^{*}$ & $.32^{* *}$ & -.011 \\
\hline 3. Lifetime sex partners & $.24^{* *}$ & $.51^{* *}$ & & $.90^{* *}$ & $.59^{* *}$ & .02 \\
\hline 4. Lifetime casual sex partners & $.35^{* *}$ & $.26^{* *}$ & $.73^{* *}$ & & -.16 & -.22 \\
\hline 5. Lifetime dating partners & $.46^{* *}$ & .13 & $.20^{*}$ & $.28^{* *}$ & & .12 \\
\hline 6. Partner quality & .06 & -.07 & .01 & .05 & .08 & \\
\hline
\end{tabular}

${ }^{*} p<0.05$ (two-tailed) $* * p<0.01$ (two-tailed)

\section{Gender Differences}

First, the equality of our model was tested across gender using multi-group analysis in order to determine whether there was a need to examine the theoretical model separately for men and women. An unconstrained model, wherein all parameters were allowed to vary across gender, was compared to a constrained structural weights model where paths were held equal across gender. A statistically significant change in $\chi^{2}(\Delta \mathrm{df})$ was considered evidence of gender differences. The unconstrained model fit the data reasonably well, $\chi^{2}=18.98(\mathrm{df}=10, p=.04)$, RMSEA $=$ $0.05(95 \% \mathrm{CI}=0.01-0.09), \mathrm{CFI}=.99, \mathrm{AIC}=106.97$, with the structural weights model fitting significantly less well, $\chi^{2}=64.79(\mathrm{df}=17, p=.00), \mathrm{RMSEA}=0.10$ $(95 \% \mathrm{CI}=0.77-0.13), \mathrm{CFI}=.92, \mathrm{AIC}=138.79$. There was as statistically signifi- 
cant change in model fit, $\Delta \chi^{2}(7)=45.81, p<.01$, indicating variability across gender. Specifically, in testing the equality of parameters for men and women using the critical ratios for differences test within AMOS, we found that age $(\mathrm{z}=2.17)$ and frequency of mate-poaching attempts $(\mathrm{z}=2.44)$ were more strongly related to number of lifetime dating partners among women $(z=2.18)$. For men but not women, frequency of mate-poaching attempts significantly predicted number of lifetime dating partners $(\mathrm{z}=2.26)$. Consequently, hypotheses were tested separately for men (Model 1) and women (Model 2) (see Figure 1).

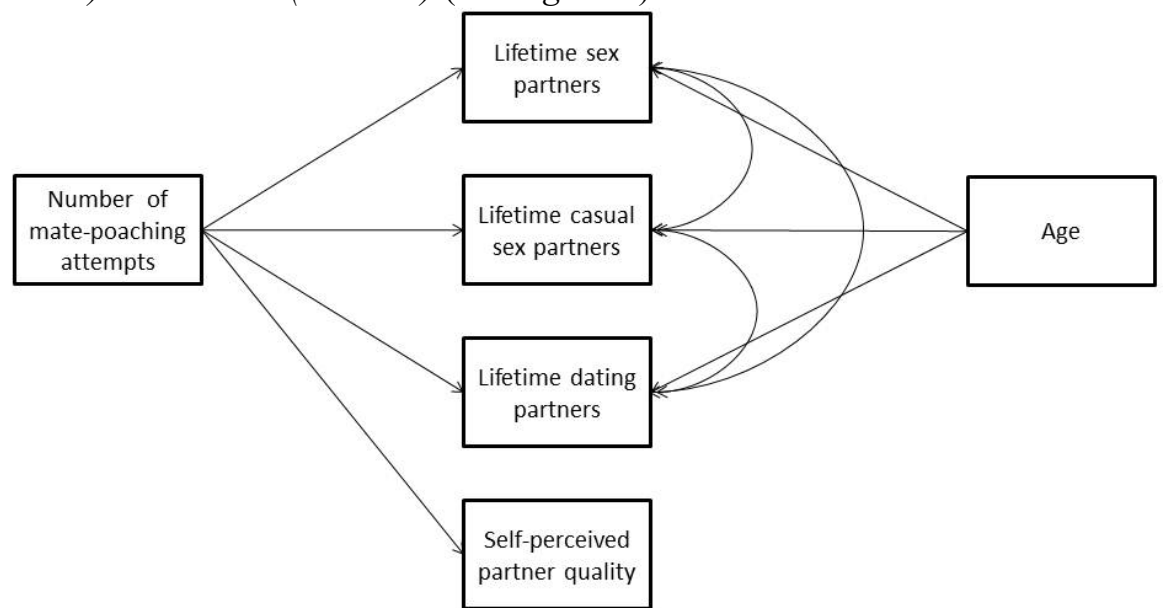

Figure 1. Path model outlining the predicted relationships between lifetime number of matepoaching attempts and mating success variables. Disturbances are not depicted

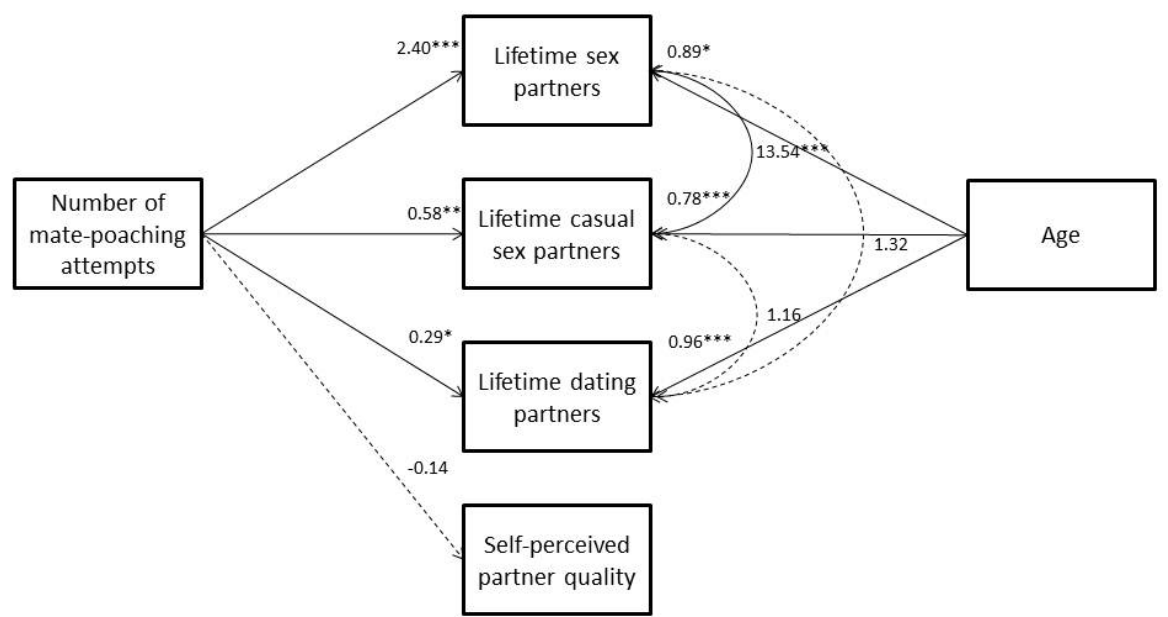

Figure 2. Results of a theoretical path model outlining links between men's lifetime number of mate-poaching attempts and mating success variables. Solid lines indicate statistically significant paths and broken lines indicate non-significant paths. Values are unstandardized regression coefficients $(b)$. Disturbances are not depicted 


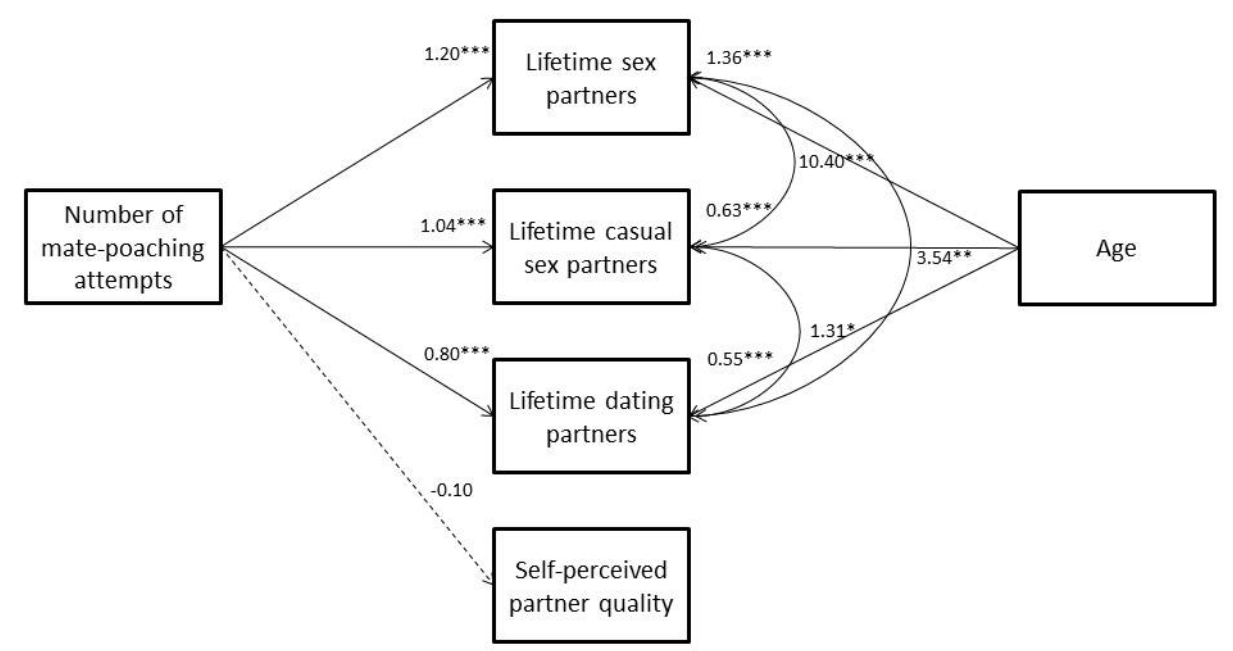

Figure 3. Results of a theoretical path model outlining links between women's lifetime number of mate-poaching attempts and mating success variables. Solid lines indicate statistically significant paths and broken lines indicate non-significant paths. Values are unstandardized regression coefficients (b). Disturbances are not depicted

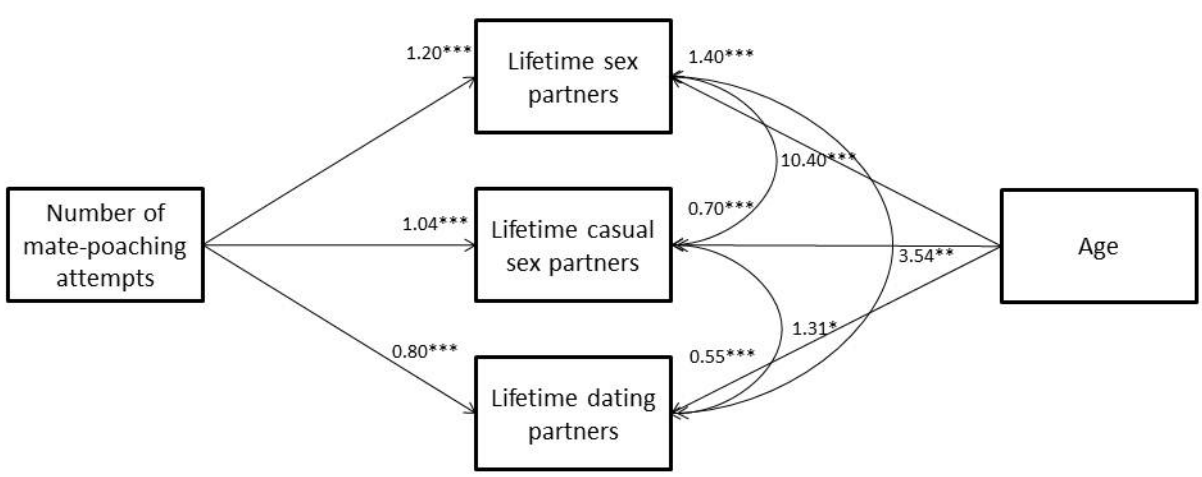

Figure 4. Results of a revised theoretical path model outlining links between women's lifetime number of mate-poaching attempts and mating success variables. Solid lines indicate statistically significant paths and broken lines indicate non-significant paths. Values are unstandardized regression coefficients $(b)$. Disturbances are not depicted

\section{MODEL FIT AND COMPARISONS}

For men, fit indices suggested that the theoretical model (Model 1) fit the data well, $\chi^{2}=3.50(\mathrm{df}=5, p=.62)$, RMSEA $=0.00(95 \% \mathrm{CI}=0.00-0.10), \mathrm{CFI}=1.00, \mathrm{AIC}$ $=47.50$ (Table 3 ). Results showed that for men, age significantly predicted lifetime number of sex partners $(b=0.89, \mathrm{p}<.05)$, lifetime number of casual sex partners $(b=0.78, p<.001)$, and lifetime number of dating partners $(b=0.96, p<.001)$. 
Number of mate-poaching attempts significantly predicted having had more lifetime sex partners $(b=2.40, p<.001)$, supporting H1a. Similarly, number of matepoaching attempts significantly predicted participants' number of lifetime casual sex partners $(b=0.58, p<.01)$, supporting H1b. Finally, number of mate-poaching attempts significantly predicted lifetime number of dating partners $(b=0.29, p<$ $.05)$, supporting H2. However, number of mate-poaching attempts did not predict perceived partner quality $(b=-0.14, n s)$, failing to support $\mathrm{H} 3$.

Next, the theoretical model was tested within a sample of women (Model 2). The model fit indices suggested adequate fit to the data, $\chi^{2}=14.72(\mathrm{df}=5, p=.02)$, RMSEA $=0.10(95 \% \mathrm{CI}=0.05-0.18), \mathrm{CFI}=0.98, \mathrm{AIC}=58.73$ (Table 3). Results showed that for women, age significantly predicted lifetime number of sex partners $(b=1.36, \mathrm{p}<.001)$, lifetime number of casual sex partners $(b=0.63, p<.001)$, and lifetime number of dating partners $(b=0.55, p<.001)$. Number of mate-poaching attempts predicted having had more lifetime sex partners $(b=1.20, p<.001)$, as well as more casual sex partners $(b=1.04, p<.001)$, supporting H1a and H1b, respectively. Among women, number of mate-poaching attempts also predicted having had more lifetime dating partners $(b=0.80, p<.001)$, supporting H2. However, similar to our sample of men, number of mate-poaching attempts by women did not predict self-perceived partner quality $(b=-0.10, n s)$, failing to support $\mathrm{H} 3$.

Table 3. Tests of the path structure model fit.

\begin{tabular}{lccccc}
\hline Nested model step & $\chi^{2}(\mathrm{DF})$ & CFI & RMSEA & $\begin{array}{r}\text { CI 95\% } \\
\text { RMSEA }\end{array}$ & AIC \\
\hline Model 1: Theoretical model (men) & $3.50(5)$ & 1.00 & .00 & $.00-.010$ & 47.50 \\
\hline Model 2: Theoretical model (women) & $14.72(5)$ & 0.98 & .10 & $.05-.18$ & 58.73 \\
\hline Model 3: Revised model (women) & $0.15(1)$ & 1.00 & .00 & $.00-.15$ & 38.11 \\
\hline
\end{tabular}

Note: $\mathrm{CFI}=$ comparative fit index; RMSEA = root mean square error of approximation; and $\mathrm{AIC}=$ Akaike information criterion; $\mathrm{N}_{\mathrm{men}}=124, \mathrm{~N}_{\mathrm{women}}=147$.

Empirical model trimming (KLINE 2005) improved the overall fit for the model of women's mate-poaching by removing the non-significant parameters for perceived mate-quality, $\chi^{2}=0.15(\mathrm{df}=1, \mathrm{p}=.73)$, RMSEA $=0.00(95 \% \mathrm{CI}=0.00$ $-0.15), \mathrm{CFI}=1.00, \mathrm{AIC}=38.11$ (Table 3). Results remained consistent with the a-priori model. For women, age significantly predicted lifetime number of sex partners $(b=1.40, \mathrm{p}<.001)$, lifetime number of casual sex partners $(b=0.70, p<$ $.001)$, and lifetime number of dating partners $(b=0.55, p<.001)$. Number of matepoaching attempts predicted having had more lifetime sex partners $(b=1.20, p<$ $.001)$, as well as more casual sex partners $(b=1.04, p<.001)$, supporting H1a and $\mathrm{H} 1 \mathrm{~b}$, respectively. Among women, number of mate-poaching attempts also predicted having had more lifetime dating partners $(b=0.80, p<.001)$, supporting $\mathrm{H} 2$. 


\section{DISCUSSION}

Wherever there are cultural expectations of monogamy, there are individuals who are willing to circumvent those expectations (see SCHMITT et al. 2004; SCHMITT and BUSS 2001). Mate-poachers do so by enticing a pair-bonded individual away from their current partner for a relationship that can range from a brief sexual liaison to the establishment of a new exclusive romantic dyad. Despite the multifarious economic and interpersonal costs associated with infidelity, such as relationship dissolution/divorce (e.g. GOTTMAN 1999), risk for communicable disease (HARRIS 2003; SIMKINS 2005; WRIGHT and RODWAY 1988), intimate partner violence (SHACKELFORD et al. 2005), as well as the dangers more specifically associated with poaching behavior (e.g., violent retaliation by the poachee; BUSS 2000; DAVIES et al. 2010), surprisingly little empirical research has been undertaken to determine the benefits of mate-poaching behavior.

In the present study, we tested the evolutionary hypothesis that mate-poaching behavior opens up a wider assortment of mating possibilities, including highly valued members of the opposite sex. Thus we predicted that the frequency with which individuals attempt a mate-poach would predict the mating success of the poacher, either in the way of general sexual access to members of the opposite sex, access to casual sex partners, having more dating partners, or through acquiring higherquality partners. Controlling for participant age, and consistent with our predictions, men who more frequently attempted mate-poaching were more likely to report having had more lifetime sexual partners (H1a) and more casual sex partners (H1b) compared to less-successful poachers. These findings seem to indicate that men who attempt mate-poaching are also better able to accrue sex partners. Over human evolutionary history, it is reasonable to suspect that obtaining access to more sex partners offered men more frequent sex and a greater diversity of mates to inseminate, thereby increasing their odds of reproduction. Indeed, access to multiple sex partners through serial monogamy has been linked to male reproductive success (JOKELA et al. 2010). RHODES, SIMMONS and PETERS (2005) suggest mating success in the way of sexual behavior is a sufficient index of reproductive success in ancestral times; however, modern day contraception attenuates this link between mating success translating into reproductive success.

Mate-poaching attempts by men also significantly predicted having had more romantic dating relationships. Monogamy (e.g., exclusive dating relationships) among humans is thought to be an adaptive response to selection pressures, possibly resulting from sexual competition factors, such as womens' preference for men who will invest in offspring, or from the necessity of bi-parental care (e.g., LANCASTER and LANCASTER 1987; WASHBURN and LANCASTER 1966). Consequently, many men enter into monogamous or serially-monogamous relationships (MILLER et al. 2002). Males who are successful in their efforts to poach may gain greater access to such relationships, ultimately benefiting their mating success. In a similar vein, BUSS (2004) suggests a number of adaptive benefits for long-term mating in men. 
These include but are not limited to the following: (1) repeated sexual access to a woman increases the odds of both conception and paternity certainty; (2) paternity certainty increases the chances men will divest their resources to their children which in turn allows the offspring to fare better than their counterparts with noninvesting fathers; (3) in ancestral times women would sometimes require an indication of commitment (even at the minimal level) prior to consenting to having sex. Thus, men would need to signal to women their interests at some capacity beyond a single sexual encounter to attract a mate at all; (4) since women prefer men who are committed for long-term relationships, men are pressured to adopt a long-term mating strategy for the purposes of being able to select from a wider range of partners in the mating pool thereby improving their chances to secure a woman with more attractive features.

Similar to our findings for men, controlling for age, women who reported more mate-poaching attempts also reported having had more lifetime sex partners, more lifetime casual sex partners, and more lifetime dating partners compared to lessfrequent poachers. Women might become involved with multiple sex partners in order to procure good genes and/or to switch or upgrade to a more desirable partner (BAKER and BELLIS 1995; GOETZ et al. 2005; GREILING and BUSS 2000).

Another finding of interest is that the number of women's mate-poaching attempts predicted having had a greater number of lifetime dating partners. Women are more likely to desire a long-term romantic relationship compared to men (BUSS 1994 ) as evidenced by the men's desire for a greater number of lifetime and casual sex partners (BUSS 1989; JOKELA et al. 2010). Although women engage in casual sex, they are far more likely than men to desire a long-term romantic partner that can offer stability and resources over a sustained period of time (BUSS 1989; BUSS 1994; ELLIS 1992). Accordingly, many men in modern western society enter into and engage in long-term romantic pair-bonds. Men and women may poach with the intention to date their target. In support of this, research has shown that across cultures, the proportion of men poaching for long-term versus short-term relationship formation is roughly equal, whereas the proportion of females poaching for longterm relationship formation is greater than the proportion of women who poach for the purpose of establishing short-term relations (SCHMITT et al. 2004).

Taken together, our findings suggest that both men and women may benefit from attempts at mate-poaching. This finding is consistent with other studies showing that women (and men) who are less adept at competing for mates have fewer dating partners (ARNOCKY and VAILLANCOURT 2012) and later onset of sexual behavior (WHITE, GALLUP and GALLUP 2010).

SCHMITT and BUSS (2001) suggested that mate-poaching is an adaptive mating tactic, and for the last decade this assumption went untested. To the best of our knowledge, no published study has supported or disconfirmed the efficacy of matepoaching behavior for improving mating success. It is important to consider that simply because a behavior exists and is widespread, does not mean this is evidence 
for its adaptive value. The present study begins to build support that mate-poaching can lead to mating success.

\section{Limitations and future directions}

The most significant limitation of the present study lays in the cross-sectional nature of the design. Following recent longitudinal work on the efficacy of other forms of intrasexual competition, such as aggressive behavior (e.g., ARNOCKY and VAILLANCOURT 2012), researchers might benefit from assessing of propensity for mate-poaching, and then assessing mating success (or costs of mate-poaching) at a later point in time. Researchers might also attempt to replicate the findings of this study across different age-ranges in order to improve generalizability. Given the exploratory nature of this study, we focused on young adulthood given that this is when individuals are at, or nearing, their reproductive peak (SHACKELFORD, POUND and GOETZ 2005). Young adults are simultaneously more intrasexually competitive than are older adults (BUSS 1998; SHACKELFORD et al. 2005). Sampling older participants retrospectively might provide the additional benefit of offering insight into the relationship between mate-poaching and reproductive behavior.

Another limitation may be our use of a brief measure of mate-value, which focused on attractiveness, status, and sexual desirability of participants' recent mates. Mate-value is a diverse and multifaceted construct (BUSS 1989). The null findings in the present study for a link between number of mate-poaching attempts and partner mate-value (H3) may be re-examined using a more comprehensive mate-value inventory modified to apply to rating of current or recent partners (FIGUEREDO, SEFCEK and JONES 2006; KIRSNER, FigUEREDO and JACOBS 2003). Researchers might also consider examining the perceived mate-values of poached versus nonpoached partners to determine whether mate-poachers can truly obtain higherquality partners via mate-poaching. In a similar vein, it would be of interest to determine whether short versus long-term poaches relate differently to mate-value. One might expect that short-term poaching would relate more strongly to physical and sexual partner mate-value traits, whereas poaching for long-term purposes might relate more strongly to positive personality and intelligence characteristics.

Previous research has elucidated a number of costs to mate-poaching, such as potential retaliation from the cuckold or from the social group at large. However, the frequencies with which these costs are experienced and individual differences in such costs have yet to be explored. This could be accomplished by surveying a sample of poachers regarding whether they had ever been attacked, denigrated, or excluded over their mate poaching behaviors. For instance, researchers could examine mate-poaching as it relates to friendship stability, negative reputation and shaming, popularity within the peer group, and social support (c.f. DAVIES et al. 2010). We suspect that individuals who attempt mate-poaching risk social sanction at the hands of a cuckold or the shared social network, and may have greater difficulty 
maintaining social affiliations, as compared to non-poachers. The link between mate-poaching and social standing and affiliation is a promising yet currently unexplored area of research.

\section{CONCLUSION}

DAVIES, SHACKELFORD and HASS (2007) propose that when all factors are kept equal, men and women prefer to mate with those who are unattached. Matepoaching seems to be the less preferred tactic that is often utilized by those who are unable to find a suitable unattached partner at a particular point in time, and this is not surprising given the potential limitations and costs that are associated with mate-poaching. Yet around the world, a significant proportion of men and women attempt to mate-poach. The results of this study are the first to shed light on why this might be the case. We found that attempts at mate-poaching predicted a number of mating success variables, including having more lifetime sex partners, more casual sex partners, and more dating partners in both men and women. The results speak to the adaptive nature of mate-poaching - a ubiquitous mating tactic that while socially objectionable, provides measurable benefits to the perpetrator.

\section{REFERENCES}

AbBEy, A. and Ross, L. (1996): Alcohol and dating risk factors for sexual assault among. Psychology of Women Quarterly, 20(1), 147-169.

Arnocky, S., Sunderani, S., Miller, J. and Vaillancourt, T. (2012): Jealousy mediates the relationship between attractiveness comparison and females' indirect aggression. Personal Relationships, 19(2), 290-303. doi:10.1111/j.1475-6811.2011.01362.x

ARNOCKY, S. and VAILlANCOURT, T. (2012): A multi-informant longitudinal study on the relationship between aggression, peer victimization, and adolescent dating status. Evolutionary Psychology, 10(2), 253-270.

BAKer, R. R. and Bellis, M. A. (1995): Human Sperm Competition: Copulation, masturbation and infidelity. London: Chapman and Hall.

Baumeister, R. F., CAtAnese, K. R. and Vohs, K. D. (2001): Are there gender differences in strength of sex drive? Theoretical views, conceptual distinctions, and a review of relevant evidence. Personality and Social Psychology Review, 5(3), 242-73. doi: 10.1207/ S15327957PSPR0503 5

Benshoof, L. and THORNhILL, R. (1979): The evolution of monogamy and loss of estrus in humans. Journal of Social and Biological Structures, 2, 95-106.

BERECZKEI, T. and CSANAKY, A. (1996): Evolutionary pathway of child development: Lifestyles of adolescents and adults from father-absent families. Human Nature, 7, 257-280. doi: 10.1007/BF02733397

Berscheid, E., Dion, K., Walster, E. and Walster, G. W. (1971): Physical attractiveness and dating choice: A test of the matching hypothesis. Journal of Experimental Social Psychology, 7, 173-189.

Broude, G. J. and Greene, S. J. (1976): Cross-cultural codes on twenty sexual attitudes and practices. Ethnology, 15, 409-438.

Buss, D. M. (2007): The evolution of human mating. Acta Psychologica Sinica, 39(3), 502-512. 
Buss, D. M. (2006): Strategies of human mating. Psychological Topics, 15, 239-260.

Buss, D. M. (2004): Evolutionary Psychology: The New Science of the Mind. Boston, MA: Pearson.

Buss, D. M. (2000): The Dangerous Passion: Why Jealousy is as Necessary as Love and Sex. New York: Free Press.

Buss, D. M. (1994): The strategies of human mating. American Scientist, 82, 238-94.

Buss, D. M. (1989): Sex differences in human mate preferences: Evolutionary hypotheses tested in 37 cultures. Behavioral and Brain Sciences, 12, 1-49.

Buss, D. M. and SchMITT, D. P. (1993): Sexual strategies theory: an evolutionary perspective on human mating. Psychological Review, 100(2), 204-232. doi: 10.1037/0033-295X.100.2.204

BuUnK, A. P. and FisHer, M. (2009): Individual differences in intrasexual competition. Journal of Evolutionary Psychology, 7, 37-48. doi: 10.1556/JEP.7.2009.1.5

DALY, M. and WILSON, M. (1989): Homicide and cultural evolution. Ethology and Sociobiology, $10,99-110$

Davies, A. P. C., Shackelford, T. K. and Goetz, A. T. (2006a): An evolutionary psychological perspective on infidelity. In P. R. Peluso (Ed.), In Love's Debris: A Practitioner's Guide to Addressing Infidelity in Couples Therapy (Routledge series on Family Therapy). New York: Routledge.

Davies, A. P., Shackelford, T. K. and Goetz, A. T. (2006b): "Attached" or "Unattached": With whom do men and women prefer to mate, and why? Psychological Topics, 15(2), 297-314.

Davies, A. P., Shackelford, T. K. and Hass, R. G. (2010): Sex differences in the perceptions of benefits and costs of mate poaching. Personality and Individual Differences, 49, 441- 445. doi:10.1016/j.paid.2010.04.014

Davies, A. P., Shackelford, T. K. and Hass, R. G. (2007): When a poach is not a poach: Redefining human mate poaching and re-estimating its frequency. Archives of Sexual Behavior, 36, 702-716. doi: 10.1007/s10508-006-9158-8

DAwKINS, R. and KREBS, J. R. (1978): Animal signals: Information or manipulation. In J. R. Krebs and N. B. Davies (Eds). Behavioral Ecology (pp. 282-309). Oxford: Blackwell Scientific.

DEWAAL, F. (1986):Deception in the natural communication of chimpanzees. In R. W. Mitchell and N. S. Thompson (Eds), Deception (pp. 221-244). Albany, NY: State University of New York Press.

ELLIS, B. J. (1992): The evolution of sexual attraction: Evaluative mechanisms in women. In L. Cosmides, J. Tooby and J. Tooby (Eds). The Adapted Mind (pp. 195-231). Oxford: Oxford University Press.

Figueredo, A. J., SEFCEK, J. and Jones, D. N. (2006): The ideal romantic partner personality. Personality and Individual Differences, 41, 431-441. doi:10.1016/j.paid.2006.02.004

GALluP, G. and Frederick, D. A. (2010): The science of sex appeal: An evolutionary perspective. Review of General Psychology, 14, 240-250. doi:10.1037/a0020451

GANGESTAD, S. W. and THORNHILl, R. (1997): The evolutionary psychology of extrapair sex: the role of fluctuating asymmetry. Evolution and Human Behavior, 8, 69-88.

Goetz, A. T., Shackelford, T. K., Weekes-Shackelford, V. A., Euler, H. A., Hoier, S., Schmitt, D. P. and LAMunyon, C. W. (2005): Mate retention, semen displacement, and human sperm competition: A preliminary investigation of tactics to prevent and correct female infidelity. Personality and Individual Differences, 38, 749-763. doi: 10.1016/j.paid. 2004.05.028

Gottman, J. (1999): The Marriage Clinic: A Scientifically Based Marital Therapy. New York, NY: W. W. Norton. 
Graziano, W. G., Jensen-Campbell, L. A., Shebilske, L. J. and Lundgre, S. R. (1993): Social influence, sex differences, and judgements of beauty: Putting the interpersonal back in interpersonal attraction. Personality and Social Psychology, 65, 522-531. doi: 10.1037/00223514.65.3.522

Greiling, H. and Buss, D. M. (2000): Women's sexual strategies: The hidden dimension of extra pair mating. Personality and Individual Differences, 28, 929-963.

HA, T., OverbeEK, G. and EngELs, R. (2010): Effects of attractiveness and social status on dating desire in heterosexual adolescents: An experimental study. Archives of Sexual Behavior, 39, 1063-1071. doi: 10.1007/s10508-009-9561-z

HARRIS, C. R. (2003): Factors associated with jealousy over real and imagined infidelity: An examination of the social-cognitive and evolutionary psychology perspectives. Psychology of Women Quarterly, 27, 319-329. doi: 10.1111/1471-6402.00112

Hill, K. and Hurtando, A. M. (1996): Ache Life History: The Ecology and Demography of a Foraging People. New York: Aldine de Gruyter.

Hodges-Simeon, C. R., Gaulin, S. J. C. and Puts, D. A. (2011): Voice correlates of mating success in men: Examining "contests" versus "mate choice" modes of sexual selection. Archives of Sexual Behavior, 40, 551-557. doi:10.1007/s10508-010-9625-0.

JOKELA, M. (2009): Physical attractiveness and reproductive success in humans: Evidence from the last 20th century United States. Evolution and Human Behavior, 30, 342-350. doi: 10.1016/j.evolhumbehav.2009.03.006

Jokela, M., Rotkirch, A., Rickard, I. J., Pettay, J. and LummaA, V. (2010): Serial monogamy increases reproductive success in men but not in women. Behavioral Ecology, 21(5), 906912. doi: 10.1093/beheco/arq078

Kalichman, S. C., Heckman, T. and Kelly, J. A. (1996): Sensation seeking as an explanation for the association between substance use and HIV-related risky sexual behavior. Archives of Sexual Behavior, 25(2), 141-154. doi: 10.1007/BF02437933

KENNY, D. A. (2000): Measuring Model Fit. URL: www.adv-energy.com/ dakenny/causalm.htm

KLINE, R. B. (2005): Core techniques: Details of path analysis. Kline, R. B., Kenny, D. (Eds), Principles and Practice of Structural Equation Modelling (pp. 123-164). New York, NY: Guildford.

Kirsner, B. R., Figueredo, A. J. and Jacobs, W. J. (2003): Self, friends, and lovers: structural relations among Beck Depression Inventory scores and perceived mate values. Journal of Affective Disorders, 75, 131-148. doi: 10.1016/S0165-0327(02)00048-4

LANCASTER, J. B and LANCASTER, C. (1987): The watershed: Change in parental-investment and family-formation strategies in the course of human evolution. In: Lancaster, J. B, Altmann, J, Rossi, A. S. and Sherrod, L. R., (Eds). Parenting Across the Life Span: Biosocial DimenSions (pp. 187-205). New York: Aldine de Gruyter.

Marlowe, F. (2000): Paternal investment and the human mating system. Behavioral Processes, $51,45-61$.

Miller, G. F. (2000): The Mating Mind: How Sexual Choice Shaped the Evolution of Human Nature. New York, NY: Doubleday.

Miller, L. C., Putcha-Bhagavatula, A. and Pedersen, W. C. (2002): Men's and women's mating preferences: Distinct evolutionary mechanisms? Current Directions in Psychological Science, 11, 88-93. doi: 10.1111/1467-8721.00175

PARKer, J. and BurKLEY, M. (2009): Who's chasing whom? The impact of gender and relationship status on mate poaching. Journal of Experimental Social Psychology, 45, 1016-1019. doi: 10.1016/j.jesp.2009.04.022

Place, S. S., TodD, P. M., Lars, A. and Asendorpf, J. B. (2010): Humans show mate copying after observing real mate choices. Evolution and Human Behavior, 31, 320-325. doi: 10.1016/j.evolhumbehav.2010.02.001 
Rhodes, G., Simmons, L. W. and Peters, M. (2005): Attractiveness and sexual behavior: Does attractiveness enhance mating success? Evolution and Human Behavior, 26, 186-201. doi: 10.1016/j.evolhumbehav.2004.08.014

SchmitT, D. P. (2002): A meta-analysis of sex differences in romantic attraction: Do rating contexts moderate tactic effectiveness judgements? British Journal of Social Psychology, 41, 387-402. doi: 10.1348/014466602760344278

SchmitT, D. P., et al. (2004): Patterns and universals of mate poaching across 53 nations: The effects of sex, culture, and personality on romantically attracting another person's partner. Journal of Personality and Social Psychology, 86(4), 560-584. doi: 10.1037/00223514.86.4.560

SchmitT, D. P. and Buss, D. M. (2001): Human mate poaching: Tactics and temptations for infiltrating existing mateships. Journal of Personality and Social Psychology, 80, 894-917. doi: 10.1037/0022-3514.80.6.894

SChMitT, D. P. and SHACKelford, T. (2003): Nifty ways to leave your lover: The tactics people use to entice and disguise the process of human mate poaching. Personality and Social Psychology Bulletin, 29(8), 1018-1035. doi: 10.1177/0146167203253471

Schmitt, D. P., Shackelford, T., Duntley, J., Tooke, W. and Buss, D. M. (2001): The desire for sexual variety as a tool for understanding basic human mating strategies. Personal Relationships, 8, 425-455. doi: 10.1111/j.1475-6811.2001.tb00049.x

Schroder, K. E., Carey, M. P. and Vanable, P. A. (2003): Methodological challenges in research on sexual risk behavior: I. Item content, scaling, and data analytical options. Annals of Behavioral Medicine, 26(2), 76-103.

Shackelford, T. K., Goetz, A. T., Buss, D. M., Euler, H. A. and Hoier, S. (2005): When we hurt the ones we love: Predicting violence against women from men's mate retention tactics. Personal Relationships, 12, 447-463. doi: 10.1111/j.1475-6811.2005.00125.x

Shackelford, T. K., Pound, N. and Goetz, A. T. (2005): Psychological and physiological adaptation to human sperm competition. Review of General Psychology, 9, 228-248. doi: 10.1037/1089-2680.9.3.228

Simkins, L. D. (1995): Risk of HIV transmission in sexual behaviours of college students. PsyChological Reports, 76(3), 787-789. doi: 10.2466/pr0.1995.76.3.787

Smith, R. L. (1984): Human sperm competition. In R. L. Smith (Ed.), Sperm Competition and the Evolution of Animal Mating Systems (pp. 601-660). New York: Academic Press.

Sprecher, S. and HATfield, E. (2009): Matching hypothesis. In H. Reis and S. Sprecher (Eds) Encyclopedia of Human Relationships. New York: SAGE.

Sunderani, S., ARNOCKY, S. and VaillancourT, T. (2013): Individual differences in mate poaching: An examination of hormonal, dispositional, and behavioral mate-value traits. Archives of Sexual Behavior, 42(4), 533-542. doi: 10.1007/s10508-012-9974-y

Trivers, R. L. (1972): Parental investment and sexual selection. In B. Campbell (Ed.) Sexual Selection and the Descent of Man, 1871-1971 (pp 136-179). Chicago, Aldine.

Trivers, R. L. (1985): Social Evolution. Menlo Park, CA: Benjamin/ Cummings.

Uller, T. and Johansson, L. C. (2003): Human mate choice and the wedding ring effect: Are married men more attractive? Human Nature, 14, 267-276. doi: 10.1007/s12110-003$1006-0$

VolAnd, E. and ENGEL, C. (1990): Female choice in humans: A conditional mate selection strategy of the Krummhorn Women (Germany, 1720-1874). Ethology, 84, 144-154. doi: 10.1111/j.1439-0310.1990.tb00791.x

VORACEK, M. (2005): Shortcomings of the sociosexual orientation inventory: Can psychometrics inform evolutionary psychology? Behavioral and Brain Sciences, 28, 296-297.

WALSTER, E, ARONSON, J, ABrahams, D and RotTMAn, L. (1966): Importance of physical attractiveness in dating behaviour. Journal of Personality and Social Psychology, 4(5), 508-516. 
WASHBURN, S. L. and LANCASTER, C. S. (1966): The evolution of human hunting. In: Lee, R. and DeVore, L, (Eds). Man the Hunter (pp 293-320). Chicago: Aldine de Gruyter.

WAYNFORTH, D. (2007): Mate choice copying in humans. Human Nature, 18, 264-271. doi: $10.1007 / \mathrm{s} 12110-007-9004-2$

WeEden, J. and SABINI, J. (2007): Subjective and objective measures of attractiveness and their relation to sexual behavior and sexual attitudes in university students. Archives of Sexual Behavior, 36, 79-88. doi: 10.1007/s10508-006-9075-x

White, D. D., Gallup, A. C. and GalluP, G. G. Junior. (2010): Indirect peer aggression in adolescence and reproductive behavior. Evolutionary Psychology, 8, 49-65.

Wright, M. and RoDwAy, M. (1988): Sexually transmitted disease: Psychological parameters and implications for social work practice. Journal of Social Work and Human Sexuality, 6(2), 21-35. doi: 10.1300/J291v06n02_03

YASUI, Y. (1997): A "Good-Sperm" model can explain the evolution of costly multiple mating by females. The American Naturalist, 149(3), 573-584. 